\title{
Laporan Tahunan Berbasis Maqasid Syariah
}

\author{
Bernad Hananto ${ }^{1}$, Iin Masriah ${ }^{2}$ \\ ${ }^{1}$ Sharia Economic Research and Consulting Institution, bernadhananto@gmail.com \\ 2 STAI Pelita Bangsa, iinmasriah8@gmail.com
}

\section{A R T I C L E I N F O}

\author{
Article history: \\ Received : 15/11/2020 \\ Revised : 16/11/2020 \\ Accepted : 16/11/2020
}

Key words:

Sharia Economic, Maqasid Sharia, Sharia Principles, Annual Reports, Entitas Sharia, Islamic Banks, Sharia Corporate Identities, Social Responsibilities.

DOI:

Doi/org/10.37366/jespb.v5i02.114

\begin{abstract}
A B S T R A C T
By revealing the Maqasid Sharia into the annual report, it can be understood that the entity has sharia principles. This study intends to describe the Maqasid Sharia to be an items that is relevant to the business aspects of the Islamic business entity. In this study it was found that the five principles of maqasid sharia can be translated into more detailed items, the principle of guarding religion (hifzh al diin) is how entities play a role in syiar, the spread of religion, sodaqoh / helping fellow human beings and how the mission of the entity is explained in accordance with maqasid sharia, the principle of safeguarding the soul (hifzh al nafs) is where the role of the entity can provide a sense of fairness, comfort, security and fairness and the development of personality, the principle of safeguarding intelect (hifzh al aql) is to play a role in the development of human resources, the principle of safeguarding posterity (hifzh al nasl) is to maintain health, a decent life, preserve human beings also means maintaining the preservation of the environment or ecosystem, so as to ensure the resources of all time, the principle of safeguarding wealth (hifzh al mal) is the principle of how the wealth is acquired / developed and how the wealth is distributed.
\end{abstract}

\begin{abstract}
A B S T R A K
Dengan mengungkap Maqasid Syariah kedalam laporan tahunan maka dapat dipahami bahwa entitas tersebut berprinsip syariah. Penelitian ini bermaksud untuk menjabarkan maqasid syariah menjadi item item yang relevan dengan aspek usaha dari entitas usaha syariah. Dalam penelitian ini ditemukan bahwa lima prinsip maqasid syariah dapat dijabarkan ke item item yang detail lagi, prinsip menjaga agama (hifzh al diin) adalah bagaimana entitas berperan dalam syiar, penyebaran agama, sodaqoh/menolong sesama manusia dan visi, misi entitas, prinsip menjaga jiwa (hifzh al nafs) adalah dimana peran entitas dapat memberikan rasa adil, nyaman, aman serta pengembangan kepribadian, prinsip menjaga akal (hifzh al aql) adalah berperan dalam pengembangan sumber daya manusia, prinsip menjaga keturunan (hifzh al nasl) adalah menjaga kesehatan, hidup yang layak, menjaga kelestarian manusia juga berarti menjaga kelestarian lingkungan hidupnya atau ekosistem, agar terjamin sumber daya sepanjang masa, prinsip menjaga harta (hifzh al mal) adalah prinsip bagaimana harta itu didapat/dikembangkan dan bagaimana harta tersebut didistribusikan.
\end{abstract}

\section{PENDAHULUAN}

Berdasarkan Undang-undang No. 25 tahun 2007 Tentang Penanaman Modal, pasal Pasal 15, bahwa Setiap penanam modal berkewajiban: a. menerapkan prinsip tata kelola perusahaan yang baik; b. melaksanakan tanggung jawab sosial perusahaan; c. membuat laporan tentang kegiatan penanaman modal dan menyampaikannya kepada Badan Koordinasi Penanaman Modal; d. menghormati tradisi budaya masyarakat sekitar lokasi kegiatan usaha penanaman modal; dan e. mematuhi semua ketentuan peraturan perundang undangan, dan selanjutnya pada Pasal 16, Setiap 
penanam modal bertanggung jawab: a. menjamin tersedianya modal yang berasal dari sumber yang tidak bertentangan dengan ketentuan peraturan perundang-undangan; b. menanggung dan menyelesaikan segala kewajiban dan kerugian jika penanam modal menghentikan atau meninggalkan atau menelantarkan kegiatan usahanya secara sepihak sesuai dengan ketentuan peraturan perundang-undangan; c. menciptakan iklim usaha persaingan yang sehat, mencegah praktik monopoli, dan hal lain yang merugikan negara; d. menjaga kelestarian lingkungan hidup; e. menciptakan keselamatan, kesehatan, kenyamanan, dan kesejahteraan pekerja; dan f. mematuhi semua ketentuan peraturan perundang undangan, pada Pasal 17 selanjutnya bahwa Penanam modal yang mengusahakan sumber daya alam yang tidak terbarukan wajib mengalokasikan dana secara bertahap untuk pemulihan lokasi yang memenuhi standar kelayakan lingkungan hidup, yang pelaksanaannya diatur sesuai dengan ketentuan peraturan perundang-undangan. Sejalan dengan kewajiban dan tanggung jawab diatas maka diwajibkan perusahaan membuat laporan tahunan sebagaimana diatur dalam Undang Undang no.40 tahun 2007, tentang Perseroan Terbatas pada pasal 66, maka direksi diwajibkan membuat laporan tahunan kepada RUPS setelah ditelaah oleh Komisaris, laporan tahunan tersebut sekurang kurangnya memuat laporan keuangan, laporan kegiatan perusahaan, laporan pelaksanaan tanggun jawab sosial, masalah yang timbul pada tahun buku yang mempengaruhi perusahaan, pengawasan yang dilakukan oleh komisaris, gaji, tunjangan dan lainnya untuk direksi dan komisaris, pada Peraturan Bank Indonesia Nomor 8/4/PBI/2006
Tentang Pelaksanaan Good Corporate Governance bagi Bank Umum, pasal 61, bahwa Bank wajib menyusun laporan pelaksanaan Good Corporate Governance pada setiap akhir tahun buku. Aktivitas pelaksanaan dan pelaporan telah diatur dalam undang undang hanya saja detail dan petunjuk pelaksanaan nya belum diatur lebih lanjut.

Institusi keuangan syariah di Indonesia membuat laporan tahunan setiap tahunnya, baik itu untuk memenuhi tuntutan undang undang dan peraturan yang berlaku maupun sebagai sarana pertanggung jawaban dan keterbukaan informasi kepada stake holder, dan juga laporan tahunan berdampak kepada citra perusahaan, laporan tahunan dibuat atas dasar kegiatan dan kejadian yang terjadi pada bank sepanjang tahun laporan, dan ini merupakan bentuk pertanggung jawaban manajemen kepada stake holder dan juga sebagai bentuk transparansi, dengan komunikasi yang tepat, perusahaan dapat membangun reputasi mereka, (Hanifa, 2007), laporan tahunan telah digunakan oleh investor sebagai sumber informasi utama, (Harahap, 2002), informasi yang dibutuhkan tidak hanya terkait indikator keuangan tapi juga apakah tindakan mereka sesuai atau tidak dengan peraturan syariah, (Harahap, 2002), para pemangku kepentingan menyadari pentingnya informasi status halal dan haram berdasarkan syariah yang diungkap dalam tanggung jawab sosial, (Othman et all, 2009) perlu pembuktian oleh pebisnis Muslim bahwa mereka beroperasi sesuai dengan hukum Islam, (Othman et all, 2010), Manajer Islamic Bank perlu berkomunikasi lebih efektif dan menghindari ambigu gaya komunikasi, karena ini memiliki implikasi religius yang penting serta implikasi terhadap citra dan reputasi perusahaan, (Hanifa et 
al, 2007). Bagi stake holder laporan tahunan merupakan informasi yang dapat memberikan gambaran tentang profile bank, profile manajemen, bagaimana bank dikelola dan dapat pula memberikan gambaran yang jelas tentang kinerja dan pencapaian, baik itu kinerja ekonomi maupun non ekonomi selama tahun laporan, salah satu cara di mana informasi tentang identitas perusahaan (misalnya ideologinya, mengelola filosofi manajemen, produk, komitmen kepada masyarakat, dll.) dikomunikasikan adalah melalui laporan tahunan perusahaan, (Haniffa et al, 2007), berusaha untuk beralih dari memanfaatkan praktik kapitalistik yang terutama berkaitan dengan pengungkapan, indikator keuangan dan terhadap sistem yang juga mempertimbangkan keadilan, keadilan, dan praktik etis, (Harahap, 2002), dalam kegiatan bisnis Islam menuntut keadilan yang diarahkan pada hak orang lain, hak lingkungan sosial, hak alam semesta. Dengan demikian, seiring dengan operasi bisnis keseimbangan sosial dan keseimbangan alam harus dijaga, Siswanti et al (2017), dalam laporan tahunan pengungkapan tanggung jawab sosial dikembangkan agar dapat menyajikan aspek aspek religi, (Novrizal et al, 2016), pengungkapan identitas perusahaan Islam, Islamic Corporate Identity (ICI) melalui laporan tahunan (annual report) seharusnya memberikan pengaruh yang baik bagi reputasi perbankan syariah dan ini menjadi alasan perbankan syariah membuat laporan tahunan yang berbeda dengan perbankan konvensional, (Romadhani et al, 2015).

Undang undang No.40 tahun 2007, tidak mengatur secara detail mengenai isi maupun format dari laporan, sehingga perusahaan dapat memuat laporan sesuai dengan keinginannya (sukarela), GRI
G3 Sustainability Reporting Guidelines merupakan standar pelaporan yang diterima secara umum dan paling banyak digunakan oleh perusahaan perusahaan didunia, Fitria et all, 2010, bank syariah masih menggunakan indikator Global Repoting Initiative (GRI) untuk mengungkap CSR, (Sunarsih et all, 2016) pengungkapan ini seperti yang lazim digunakan oleh bank konvensional, sehingga belum dapat memberikan panduan maksimal yang berdampak tergambarnya identitas syariah. Panduan pelaporan yang ada di peruntukan bagi institusi usaha konvensional secara umum, sedangkan institusi syariah memiliki karakteristik yang berbeda sehingga aspek aspek syariah perlu di tampilkan dalam laporan tahunan, dengan demikian panduan laporan tahunan yang berbasis syariah perlu untuk dirumuskan sehingga institusi syariah dapat menggunakannya sebagai acuan guna menampilkan aspek syariah dalam laporan tahunan dan juga dapat memenuhi kebutuhan informasi bagi stake holdernya, prinsip Syariah mestinya ada dalam laporan tahunan sehingga dapat memenuhi kebutuhan informasi tentang pelaksanaan syariah serta pencapaian tujuan syariah (maqasid syariah) pada institusi syariah dan juga hal ini dapat menjadi pembeda antara laporan tahunan institusi syariah dengan institusi konvensional.

Berikut adalah penelitian terdahulu mengenai pengungkapan dalam laporan tahunan serta faktor faktor yang mempengaruhinya, dan penelitian tentang corporate identity, maslahah dan maqasid syariah; survei periode 3 tahun menunjukkan keseluruhan Ethical Identity of Islamic rata-rata hanya satu Islamic Bank dari tujuh yang disurvei berada di atas rata-rata, (Haniffa et al, 2007); hasil penilaian aspek pada checklist kemudian dituangkan dalam 
indeks EII (Ethical Identity Index), dari hasil perhitungan EII, dapat diketahui bahwa praktik pengungkapan laporan tahunan bank umum syariah untuk tahun 2007, 2008, dan 2009 telah mendekati standar pelaporan ideal yang mencerminkan Islamic Corporate Identity, (Paramitasari, 2012); penelitian 18 bank syariah di Indonesia pada untuk tahun penelitian 2010 sampai 2011 dengan hasil bahwa company size dan profitability mempengaruhi pengungkapan Islamic Social Responsibility sedangkan komposisi komisaris independen dan umur perusahaan tidak berpengaruh, (Lestari, 2013); Ukuran Dewan Komisaris terbukti memiliki pengaruh positif signifikan, terhadap pengungkapan Islamic Social Reporting pada perbankan syariaah di Indonesia sedangkan ukuran dewan pengawas syariah tidak terbukti berpengaruh terhadap pengungkapan Islamic Social Reporting pada perbankan syariah di Indonesia, (Khoirudin, 2013); Keagungan dan keluhuran Syariah Islam termanifestasikan pada kompatibilitas hukum-hukum Syariah dengan perkembangan kehidupan manusia lantaran ruh maslahah yang menggerakkannya, (Asmawi, 2014); Islamic Corporate Identity (ICI) memiliki pengaruh pada CAR sebesar 85,30\%, sebesar 92,67\% FDR, NPF sebesar 95,2\%. Identitas Korporat Islam (ICI) tidak berpengaruh pada ROA, ROE, dan ROA, (Romadhani et al, 2015); Hasil penelitian menunjukkan bahwa hanya ukuran yang mempengaruhi pengungkapan Islamic Social Responsibility, sehingga semakin besar total aset pengungkapan yang lebih besar dari Pelaporan Sosial Islam. Penerbitan sukuk tidak berpengaruh karena struktur kepemilikan perusahaan di Asia, termasuk Indonesia cenderung konsentrasi kepemilikan keluarga. Profitabilitas tidak berpengaruh karena perusahaan memiliki perspektif yang berbeda dengan Pelaporan Sosial Islam, (Sunarsih et al, 2016); hasil penelitian menunjukkan bahwa konsep menjaga agama terletak pada kepatuhan terhadap syariah, yaitu kewajiban menggunakan jilbab bagi wanita. Konsep menjaga jiwa dipahami sebagai kewajiban mengeluarkan zakat 2,5\% dari total penghasilan perbulan. Konsep menjaga akal dijalankan dengan mendirikan lembaga pendidikan bagi karyawan. Konsep menjaga keturunan diwujudkan dalam peningkatan kesejahteraan karyawan melalui Ittifaq muamalat yang mengatur semua jenis kebutuhan karyawan, akhirnya konsep menjaga harta menekankan pada kesejahteraan stakeholder dan nasabah, (Muklis, 2016); hasil penelitian menunjukan bahwa jumlah dewan pengawas syariah berpengaruh signifikan terhadap pengungkapan aspek lingkungan dan aspek produk dan jasa yang ada di dalam pengungkapan Islamic Social Responsibility, (Purwanti, 2016).

\section{KAJIAN TEORI}

\subsection{TINJAUAN TEORI MAQASHID SYARIAH}

Islam sebagai agama memiliki tujuan utama yaitu sebagai rahmat bagi seluruh alam, jadi bukan hanya bagi umat islam itu sendiri akan tetapi seluruh alam dan seisinya sesuai dengan ayat dibawah ini:

"Dan tidaklah Kami mengutusmu, kecuali menjadi rahmat bagi seluruh alam" (QS. Al-Anbiya':107)

Rahmat bagi semesta alam yang merupakan tujuan utama ini lebih dikenal dengan maqasid syariah atau juga disebut maslahat, kajian tentang maqasid al-syar'iah tidak lain adalah menyangkut 
pembahasan tentang maslahat, Herawati, (2010), Maqasid al-Syari'ah telah secara langsung dinyatakan dalam Al-Qur'an dan Sunnah atau disimpulkan dari ini oleh sejumlah ulama. Semua ini membahas maksud/tujuan/alasan dari Syari'ah yang, sebagaimana diakui oleh hampir semua ahli hukum, adalah untuk melayani kepentingan (jalb almasalih) dari semua manusia dan untuk menyelamatkan mereka dari bahaya (daf 'almafasid), menurut Imām Abū Hāmid al-Ghazālī seorang reformis terkemuka dan sangat dihormati di abad ke-5 Hijriah, mengklasifikasikan maqasid ke dalam lima kategori utama, (Chapra 2008), menurut teori imam al-Ghazali, maslahah adalah: "memelihara tujuan-tujuan syari' at". tujuan syari'at meliputi lima dasar pokok, yaitu: 1) melindungi agama (hifzhaldiin); 2) melindungi jiwa (hifzh al nafs); 3) melindungi akal (hifzh al aql); 4) melindungi kelestarian manusia (hifzh al nasl); dan 5) melindungi harta benda (hifzh al mal).

Maqasid al-syariah, merupakan landasan dalam berijtihat, dalam rangka menetapkan hukum, dan juga menjadi pertimbangan bagi masalah masalah yang tidak ditemukan hukumnya secara tegas dalam nash, (Mayangsari et al, 2014), maqasid al syariah merupakan aspek penting dalam pengembangan hukum Islam sehingga hukum Islam dapat dan sangat mungkin beradaptasi dengan perubahan perubahan sosial yang terjadi di masyarakat, adaptasi yang dilakukan berpijak pada landasan yang kuat dan kokoh pada ruang lingkup syariah, (Shidiq, 2009), hukum yang merupakan hasil ijtihad tidak boleh bertentangan dengan prinsip dan nilai nilai maqasid syariah, (Auda, 2007), entitas syariah mestinya menggunakan maqasid syariah sebagai landasan dalam melakukan komunikasi dalam laporan tahunannya.

\section{METODE PENELITIAN}

Peneitian ini menggunakan metode kualitatif, dimana pendekatan yang dilakukan dengan memfokuskan penggalian berdasarkan pemaknaan dan interpretasi subjek penelitian, penelitian kualitatif mengkonstruksi realitas dan memahami maknanya. sehingga, penelitian kualitatif biasanya sangat memperhatikan proses, peristiwa dan otentisitas, (Somantri, 2005), Data yang berupa katakata atau teks tersebut kemudian dianalisis. Hasil analisis itu dapat berupa penggambaran atau deskripsi atau dapat pula dalam bentuk tema-tema. Dari data-data itu peneliti membuat interpretasi untuk menangkap arti yang terdalam. Sesudahnya peneliti membuat pemikiran pribadi (self-reflection) dan menjabarkannya dengan penelitian-penelitian ilmuwan lain yang dibuat sebelumnya, (Raco, 2010).

\section{HASIL DAN PEMBAHASAN}

Organisasi usaha yang berprinsip syariah tentunya di jalankan sesuai dengan hukum syariah yang memiliki aktivitas serta tujuan yang sesuai dengan maqasid syariah, dan ini mestinya dapat diungkap pada laporan tahunan, sehingga stake holder dapat melihat bagaimana semestinya organisasi dijalankan, untuk itu penulis mencoba memberikan gambaran detail tentang maqasid syariah yang di ungkap pada laporan tahunan, "memelihara tujuan-tujuan syari' at". tujuan syari'at meliputi lima dasar pokok, yaitu: 1) melindungi agama (hifzhaldiin); 2) melindungi jiwa (hifzh al nafs); 3) melindungi akal (hifzh al aql); 4) melindungi kelestarian manusia (hifzh al nasl); dan 5) melindungi harta benda (hifzh al mal), perlu untuk di jabarkan lagi sehingga dapat sejalan dan 
relevan dengan entitas usaha syariah agar dapat di laksanakan dan diungkap pada laporan tahunan, ada beberapa bagian (bab) dalam laporan tahunan yang bisa digunakan untuk mengungkap kebijakan, program, aktivitas dan lainnya yang dilakukan oleh manjemen yang memiliki prinsip prinsip sesuai dengan maqasid syariah, sebagai berikut:

\subsection{Melindungi Agama (hifzh al diin)}

Agama Islam merupakan suatu sistim keyakinan, penyembahan dan aturan aturan Allah yang mengatur segala kehidupan manusia dalam berbagai hubungan; baik itu dengan manusia maupun dengan Allah, kewajiban semua orang untuk menyadarkan bahwa agama merupakan kebutuhan umat manusia (Muhammaddin, 2013), menjaga agama terletak pada kepatuhan terhadap syariah, (Muklis et al, 2016).

Dalam surat Asy-Syura': 13 firman Allah mengenai penegakan agama; "Diwasiatkan-Nya kepada Nuh dan apa yang telah Kami wahyukan kepadamu (Muhammad) dan apa yang telah Kami wasiatkan kepada Ibrahim, Musa dan Isa yaitu tegakkanlah agama (keimanan dan ketakwaan) dan janganlah kamu berpecah belah di dalamnya. Sangat berat bagi orang-orang musyrik (untuk mengikuti) agama yang kamu serukan kepada mereka. Allah memilih orang yang Dia kehendaki kepada agama tauhid dan memberi petunjuk kepada (agama)-Nya bagi orang yang kembali (kepada-Nya)".

Dibawah ini adalah melindungi agama dengan tema-tema yang telah di kembangkan oleh Bedoui, menjadi tema-tema sebagai berikut; Pemenuhan Tanggung jawab Sosial dan politik, Keadilan, Persaudaraan, Kesetaraan, Saling Tolong Menolong,
Sabar, Kebijaksanaan, Kehatian hatian, Peningkatan Spiritual dan moral, Hemat, Toleransi, (Bedoui, 2012), menjaga agama adalah aktivitas pelaksanaan agama seperti pelaksanaan ibadah dan pelaporan manajemen, peran aktif dalam syiar agama, menjaga integritas dan patuh terhadap hukum dan aturan yang berlaku, aksi sosial, amanah/kepedulian terhadap stakeholder, dan juga dakwah kepada umat serta turut aktif dalam tersedianya sarana dan prasana ibadah pada lingkungan sekitar, berikut adalah aspek aspek diungkap dalam laporan tahunan yang berkaitan dengan melindungi agama adalah;

Bab Profil Perusahaan: Misi, Visi, nilai nilai, budaya perusahaan, Identitas entitas, riwayat singkat, struktur organisasi, bidang usaha, pengungkapan peranan perusahaan dalam ekonomi dan kesejahteraan masyarakat dan juga lingkungan, produk dan jasa serta layanan, jaminan/status halal pada produk dan layanan, transaksi haram, riba, maisir dan gharar, jumlah karyawan, komposisi pemegang saham, kronoligi penerbitan saham dan efek lainnya, daftar anak perusahaan, afiliasi, struktur group perusahaan, lembaga profesi penunjang, penghargaan yang diterima.

Bab Tanggung Jawab Sosial: Shodaqoh, kegiatan sosial lainnya yang bernuansa islami (perayaan hari besar, dakwah dan lainnya), peranan perusahan dan karyawan dalam membantu korban bencana alam (employee volunteerism), pemberian sumbangan bagi korban bencana alam, dukungan terhadap kegiatan kegiatan yang bersifat kebangsaan dan budaya, wakaf dan pengembangannya.

Bab Pembahasan Manajemen: Aspek pemasaran mengenai pelayanan prima, penanganan keluhan 
pelanggan, dan juga trend jumlah complain selama lima tahun, deviden, program pemilikan saham oleh karyawan/manajemen, realisasi penggunaan dana hasil penawaran umum, informasi yang mengandung benturan kepentingan, perubahan undang-undang yang berdampak pada perusahaan, kebijakan akuntansi yang digunakan serta perubahannya jika ada, informasi kelangsungan usaha.

Bab Laporan Manajemen: Laporan Dewan Komisaris, Profil Dewan Komisaris, Laporan Dewan Pengawas Syariah, Profil Dewan Pengawas Syariah, Laporan Direksi, Profil Direksi, Surat Pernyataan Tentang Tanggung Jawab Atas Kebenaran Isi Laporan Tahunan.

Bab Tata Kelola perusahaan: Pernyataan dewan pengawas mengenai kepatuhan syariah dan audit kepatuhan syariah, kode etik, komite kepatuhan, prinsip kehati hatian, juga diungkap mengenai denda/hukuman dan pelanggaran yang dilakukan serta perbaikan yang telah dan akan dilakukan, juga pada bab ini diungkap komite-komite yang ada pada perusahaan seperti komite audit, komite resiko, komite remenurasi dan lainnya serta apa yang dilakukan selama periode laporan, Kebijakan mengenai keberagaman komposisi Dewan Komisaris dan Direksi, Praktik Good Corporate Governance.

Bab Pengembangan Sumber Daya Manusia: Pengembangan spiritual karyawan perusahaan, seperti sholat berjamaah mulai dari manajemen puncak hingga bawahan, program hafidz Al Quran bagi karyawan, kebijakan mengenai pemberian ijin untuk beribadah pada hari dan jam kerja misalnya sholat, ibadah umroh, ibadah haji, juga penyediaan sarana ibadah yang layak disekitar ditempat kerja, kajian mingguan dan atau bulanan, dan juga perayaan keagamaan lainnya untuk karyawan.

\subsection{Melindungi Jiwa (hifzh al nafs)}

Menurut Imam Ghazali, Nafs memiliki dua makna, pertama adalah gairah, gairah sebagai kata komprehensif yang terdiri dari keserakahan, amarah dan atribut jahat lainnya, Nabi berkata : Musuh terbesarmu adalah hasratmu yang terbaring dikedua sisimu, makna ke Nafs yang kedua adalah jiwa, ketika Nafs menerima ketenangan dan telah menghapus gairah, hal ini disebut Nafs Mutmainnah atau jiwa yang tenang, (Ghazzali, 12th century), seperti dalam Al Quran Surat Al Fajr : 27 30; "Hai jiwa yang tenang, Kembalilah kepada Tuhanmu dengan hati yang puas lagi diridhai-Nya. Maka masuklah ke dalam jama'ah hamba-hamba$\mathrm{Ku}$, masuklah ke dalam syurga-Ku". Dan juga pada Al Quran surat As Syam, 91: 8-10; “Maka Dia mengilhamkan kepadanya (jalan) kejahatan dan ketakwaannya, sungguh beruntung orang yang menyucikannya (jiwa itu), dan sungguh rugi orang yang mengotorinya".

Nafs dalam al-Qur'an dapat diartikan sebagai kejiwaan (sisi dalam) manusia, yang menghasilkan perilaku, (Solichin, 2009), Al-Quran mengungkap istilah jiwa yang tenang (an-nafsu al muthainnah), dan juga hadist menyebut kata fitrah, keduanya adalah syarat bagi kesehatan mental yang harus dimiliki seorang muslim, mental yang yang sehat akan mampu menghadapi kenyataan hidup dengan perasaan senang, tentram dan bahagia sehingga kepribadiannya menjadi mantap dan siap berkarya bagi komunitasnya, (Fuad, 2016), kualitas nafs berpengaruh terhadap kemuliaan dan kebahagian 
seseorang. Jika kualitas nafs baik, maka baiklah perbuatan seseorang dan jika kualitas nafs itu buruk maka akan menghasilkan perbuatan yang buruk juga, (Solichin, 2009), Soft competency pada dasarnya dipengaruhi oleh jiwa yang tenang, soft competency adalah pengetahuan, sikap dan perilaku yang diperlukan untuk semua tempat kerja untuk beroperasi secara efektif, (ILO, 2015), maka aktivitas melindungi jiwa akan menghasilkan sumber daya manusia yang memiliki soft competency yang positif bagi organisasi, dibawah ini adalah Melindungi Jiwa (hifzh al nafs) dengan tema tema yang telah di kembangkan oleh Bedoui menjadi tema - tema sebagai berikut; Martabat, Kesempatan Kerja dan Berusaha, Solidaritas Keluarga dan Sosial, Kedamaian Mental dan kebahagian, Kehormatan Diri, Jaminan Hidup, Kesetaraan Sosial, Kepercayaan, (Bedoui, 2012).

Menjaga jiwa adalah kegiatan yang berkaitan dengan rasa ketenangan, keamanan, keadilan, pemenuhan atas hak asasi, pengembangan kepribadian dan soft kompetensi, pengakuan atas keberadaan dan partisipasi, dukungan perusahaan dalam menciptakan suasana bebas mengutarakan pendapat bagi seluruh karyawan, kritik dan saran yang positif, sehingga dapat membentuk pribadi pribadi yang siap untuk berkembang (pengembangan kompetensi) dan dapat menghadapi pekerjaan dan tantangan kerja, berikut adalah aspek aspek diungkap dalam laporan tahunan yang berkaitan dengan menjaga jiwa;

\section{Pengembangan Sumber Daya Manusia: Survey} kepuasan karyawan, kesehatan dan keselamatan kerja serta komitmen dalam mengadakan sarana dan prasarana kerja, kebijakan mengenai kesempatan berkarier yang sama bagi seluruh karyawan, kebijakan incentive/bonus dan kinerja, kebijakan jam kerja maximum, jumlah karyawan dalam 2 atau 3 tahun sebelumnya (komposisi) dan jumlah karyawan keluar (resign), jumlah rekruitmen, komitmen manajemen dalam menciptakan keseimbangan pekerjaan dan kehidupan, aktivitas karyawan seperti club karyawan seperti olah raga, pecinta alam, family gathering, kebebasan berpendapat, prosedur dan lainnya, program karyawan terbaik tahunan, program suksesor bagi posisi tertentu, jaminan hari tua (pension) dan juga program pra pension, ikut serta dalam salary survey, jumlah rekrutmen bagi lulusan baru, dan jumlah karyawan yang berkebutuhan khusus, seperti ex pengguna narkoba, penderita cacat tubuh, kesetaraan gender.

\subsection{Melindungi Akal (hifzh al aql)}

Akal memiliki beberapa arti yang pertama adalah kecerdasan yang sifatnya sejati dari hal hal yang material dan terletak dalam jiwa, arti kedua adalah kekuatan untuk memahami rahasia dari berbagai pembelajaran, (Ghazzali, 12th century).

Q.S. Al-Baqarah ayat 164 yang berbunyi : "Sesungguhnya pada penciptaan langit dan bumi, pergantian malam dan siang, kapal yang berlayar di laut dengan (muatan) yang bermanfaat bagi manusia, apa yang diturunkan Allah dari langit berupa air, lalu dengan itu dihidupkan-Nya bumi setelah mati (kering), dan Dia tebarkan di dalamnya bermacam-macam binatang, dan perkisaran angin dan awan yang dikendalikan antara langit dan bumi, (semua itu) sungguh, merupakan tanda-tanda (kebesaran Allah) bagi orang-orang yang mengerti".

Konsep menjaga akal dijalankan dengan mendirikan lembaga pendidikan bagi karyawan, 
(Muklis et al, 2016). Berikut ini adalah melindungi Akal (hifzh al aql) dengan tema-tema yang telah di kembangkan oleh Bedoui menjadi tema-tema sebagai berikut; Pendidikan, Keuangan, Kebebasan, Tata Kelola yang baik, Pendidikan berkualitas dan terjangkau, Fasilitas Perpustakaan dan Riset, Riset, Insentif untuk kerja kreatif, (Bedoui, 2012), pengembangan akal adalah kegiatan dengan manejemen pengembangan sumber daya manusia, seperti kompetensi matrik, program training, pendidikan dan bea siswa, berikut adalah aspek aspek ditampilkan dalam laporan tahunan yang berkaitan dengan melindungi akal;

\section{Bab Pengembangan Sumber Daya Manusia:}

Program peningkatan kompetensi seperti misalnya program pengembangan karyawan, melalui training, bea siswa bagi karyawan, kompetensi dan talent manajemen, pengeluaran remenurasi dan biaya sumber daya manusia lainnya seperti training dan pengembangan.

Bab Tata Kelola perusahaan: Struktur tata kelola, daftar komisaris, daftar direktur dan daftar dewan pengawas syariah, tugas dan tanggung jawab manajemen puncak, kebijakan konflik kepentingan, dan komisi yang ada di perusahan, Program anti pencucian uang, wistle blower.

Bab Tanggung Jawab Sosia: Perpustakaan, sarana riset, bekerjasama dengan lembaga riset atau sekolah/universitas dalam hal riset, program bea siswa bagi anak kurang mampu, bea siswa keluarga karyawan.

Bab Pembahasan Manajemen: Pengembangan produk dan layanan bagi pelanggan, aspek pemasaran atas produk dan/atau jasa perusahaan, riset dan inovasi, strategi pemasaran dan pangsa pasar.

Bab Teknologi Informasi: Teknologi informasi yang ada pada perusahaan dan bagaimana kinerjanya seperti apakah pernah mengalami gangguan yang berarti bagi operasional dan jaminan keamanan data.

\subsection{Melindungi Kelestarian Manusia (hifzh al nasl)}

Kelestarian manusia adalah aktivitas menjaga kesehatan, hidup yang layak, menjaga kelestarian manusia juga berarti menjaga kelestarian lingkungan hidupnya atau ekosistem, agar terjamin sumber daya sepanjang masa, dimana menjaga melestarikan lingkungan hidup merupakan sarana yang amat penting bagi kelangsungan hidup manusia dimuka bumi,

Pada Al Quran Surat Al Baqarah: 205; “Dan apabila dia berpaling (dari engkau), dia berusaha untuk berbuat kerusakan di bumi, serta merusak tanam-tanaman dan ternak, sedang Allah tidak menyukai kerusakan".

Dan ditafsir Ibnu Katsir: "Orang munafik itu tidak mempunyai keinginan kecuali untuk membuat kerusakan semata dimuka bumi, memusnahkan tanam tanaman masksudnya tempat tanaman tumbuh, berbuah sekaligus tempat berkembang biaknya hewan hewan yang keduanya merupakan sendi hajat hidup manusia".

Ekosistem adalah merupakan hajat hidup manusia, dengan demikian pelestariannya merupakan tugas umat manusia, pelestarian lingkungan akan menjamin tersedianya sumber kehidupan bagi manusia di kemudian hari. Konsep 
menjaga keturunan diwujudkan dalam peningkatan kesejahteraan karyawan melalui Ittifaq muamalat yang mengatur semua jenis kebutuhan karyawan, (Muklis et al, 2016), di bawah ini adalah melindungi Kelestarian Manusia (hifzh al nasl) dengan tema tema yang telah di kembangkan oleh Bedoui menjadi tema - tema sebagai berikut; Integritas Keluarga, Lingkungan Sehat, Peningkatan Teknologi dan manajemen, Pengembangan Intelektual dan moral, Menekan kejahatan dan keresahan, Pendidikan moral dan duniawi, Pemenuhan kebutuhan, Pengasuhan anak yang tepat, (Bedoui, 2012), prinsip melingungi keturunan adalah adalah menjaga kesehatan, hidup yang layak, menjaga kelestarian manusia juga berarti menjaga kelestarian lingkungan hidupnya atau ekosistem, agar terjamin sumber daya sepanjang masa, berikut adalah aspek aspek dapat diungkap dalam laporan tahunan yang berkaitan dengan menjaga pelestarian Manusia;

Bab Tanggung Jawab Sosial: Bantuan dan atau donasi pendidikan dan program pengembangan pemuda, dukungan perusahaan terhadap anak yatim disekitar, program perlindungan anak, pelestarian alam, dukungan bagi perlindungan hewan dan tanaman, kebijakan dan sistim manajemen lingkungan dan bagaimana sistim tersebut dijalankan dan audit terhadap efektifitas manajemen lingkungan, dukungan perusahaan pada program anti kejahatan dan anti narkoba, perbaikan dan atau pembangunan fasilitas kebersihan, menjaga sumber air dan pencegahan pencemaran udara, produk yang ramah lingkungan.

\subsection{Melindungi Harta Benda (hifzh al mal)}

Kepemilikan harta dalam Islam dapat di uraikan sebagai berikut:
1) Pemilik mutlak terhadap segala sesuatu yang ada di muka bumi ini, termasuk harta benda, adalah Allah Swt. Kepemilikan oleh manusia bersifat relatif, sebatas untuk melaksanakan amanah mengelola dan memanfaatkannya.

2) Harta yang dimiliki manusia adalah sebagai:
a) Amanah
b) Perhiasan hidup
c) Ujian keimanan
d) Bekal ibadah

Harta yang baik harus memenuhi dua kriteria, yaitu:

1) Diperoleh dengan cara yang sah dan benar

2) Dipergunakan dengan dan untuk hal yang baikbaik di jalan Allah

Fungsi Harta Dalam Islam (Palupi, 2013);

1) Berfungsi untuk menyempurnakan pelaksanaan ibadah yang khas

2) Untuk meningkatkan keimanan (ketakwaan) kepada Allah, sebab sebuah kefakiran cenderung mendekatkan diri kepada kekufuran

3) Untuk meneruskan kehidupan dari satu periode ke periode berikutnya

4) Untuk menyelaraskan (menyeimbangkan) antara kehidupan dunia dan akhirat.

5) Untuk mengembangkan dan menegakkan ilmuilmu

6) Untuk saling tolong menolong antara kaya dan miskin

7) Untuk menumbuhkan silaturahmi

Menjaga harta menekankan pada kesejahteraan stakeholder dan nasabah, (Muklis et al, 2016), aktivitas guna memperolehan harta adalah bagian dari ibadah oleh karena itu yang dilakukan haruslah dengan prinsip kehati-hatian sehingga terlepas dari 
perihal perbuatan yang dapat merugikan orang lain dan usaha yang haram (Palupi, 2013). Dibawah ini adalah melindungi Melindungi Harta Benda (hifzh al mal) dengan tema-tema yang telah di kembangkan oleh (Bedoui, 2012), menjadi tema-tema sebagai berikut; Distribusi merata pendapatan dan kekayaan, Kejujuran, Kehormatan, Saling percaya, Tingkat Optimal Pertumbuhan, Harta Benda dan Penghematan, Penghapusan Kemiskinan, Tabungan dan Investasi, (Bedoui, 2012), prinsip menjaga harta adalah bagaimana harta itu didapat/dikembangkan dan bagaimana harta tersebut didistribusikan, berikut adalah aspek aspek ditampilkan dalam laporan tahunan yang berkaitan dengan menjaga Harta:

Tata Kelola perusahaan: Penghasilan yang mengandung Riba, kebijakan tentang keterlambatan pembayaran, penyelesaian NPF dan juga kebijakan mengenai pencadangan dan penghapusan NPF, Mengungkap adanya Kebijakan dan prosedur anti korupsi dan bagaimana kebijakan ini dijalankan, kebijakan kepatuhan dan integritas seperti anti kecurangan dalam berusaha seperti monopoli, kartel, manipulasi, judi, Implementasi Internal Control dan Internal Audit, penunjukan KAP dan External Audit, berikut adalah aspek aspek diungkap dalam laporan tahunan yang berkaitan dengan menjaga Harta.

Bab Analisa dan Pembahasan Manajemen: Kondisi ekonomi yang relavan dengan kegiatan usaha, ungkap ancaman dan peluang di masa laporan dan juga masa depan, pangsa pasar, pencapaian atas target tahunan perencanaan dengan realisasi.

Bab Iktisar Kinerja keuangan: Kinerja keuangan, Rasio keuangan, Laba per saham, perbandingan selama lima tahun atau sepanjang tahun jika entitas beroperasi kurang dari lima tahun.

Bab Ikhtisar Saham: Jumlah saham beredar, kapitalisasi pasar, harga saham tertinggi, terendah dan penutupan, serta volume perdagangan.

Bab Ikhtisar Sukuk dan Obligasi: Ikhtisar Obligasi, Sukuk atau Obligasi Konversi.

Bab Ikhtisar Operasional: Jaringan kantor, ATM, Jumlah Pegawai dan Jumlah Nasabah selama lima tahun kebelakang.

Bab Laporan Keuangan: Laporan Keuangan lengkap yang telah di audit, opini external auditor dan surat pernyataan tanggung jawab komisaris dan direksi atas laporan keuangan, ikhtisar kebijakan akuntansi, pengungkapan transaksi yang berelasi, perpajakan, zakat.

Bab Tanggung Jawab Sosial: Dukungan perusahaan pada program penghapusan kemiskinan, kemitraan, pembinaan terhadap ekonomi lemah melalui ekonomi syariah (pembinaan usaha, qardhul hasan, micro financing), pembayaran zakat dan pengelolaannya.

\section{PENUTUP}

\subsection{KESIMPULAN}

Pentingnya panduan laporan tahunan bagi entitas syariah bukan saja untuk mematuhi peraturan perundang undangan yang berlaku tetapi juga memberikan gambaran/citra tentang bagaimana sebuah entitas syariah menjalankan usahanya, panduan ini juga dapat berfungsi sebagai acuan bagi entitas syariah dalam perencanaan maupun realisasi aktivitas dalam membangun lingkungan usaha agar sesuai dengan maqasid syariah. 


\subsection{IMPLIKASI MANAJERIAL}

Diperlukan adanya standarisasi laporan tahunan bagi entitas syariah sehingga ada keseragaman bagi implementasinya dan gambaran prinsip syariah tercermin pada laporan tahunannya.

\subsection{KETERBATASAN PENELITIAN}

Penelitian ini hanya terbatas meneliti tentang item item yang bisa diungkap agar dapat memberikan gambaran maqasid syariah pada entitas usaha, dan belum memberikan gambaran seberapa baik maqasid syariah yang diungkap pada laporan tahunan.

\subsection{SARAN PENELITIAN SELANJUTNYA}

Penelitian mengenai panduan laporan tahunan yang ideal dan bagi entitas syariah harus terus dilakukan dan juga di publikasikan sehingga mendapatkan format yang ideal bagi entitas syariah, penambahan dan atau pengurangan tema atau item yang relavan bagi entitas usaha akan sangat berguna bagi pengungkapan tahunan entitas syariah, penelitian dapat di perluas lagi dengan mengukur, mengkuantifikasi, dan index atas kegiatan, aktivitas, dan data yang diungkap sehingga dapat dibandingkan antara satu entitas dengan entitas lainnya.

\section{REFERENSI}

Al-Qur'anul Karim

Undang undang No. 25 tahun 2007 Tentang Penanaman Modal.

Undang Undang no.40 tahun 2007, tentang Perseroan Terbatas.
Peraturan Bank Indonesia Nomor 8/4/PBI/2006

Tentang Pelaksanaan Good Corporate

Governance bagi Bank Umum.

Ghazzali, Ihya Ulum Id Din, Early 12th century, Translate by Fazl Ul Karim, Publish by Darul Ishaat, First Edition, 1993

Chapra M. Umer, The Islamic Vision of Development in the Light of Maqāsid AlSharīah, Islamic Research and Training Institute Islamic Development Bank Jeddah, 2008.

Siswanti Indra, Ubud Salim, Eko Ganis Sukoharsono, Siti Aisjah, The Impact of Islamic Corporate Governance, Islamic Intellectual Capital and Islamic Financial Performance on Sustainable Business Islamic Banks, 2017.

Somantri Gumilar Rusliwa, Memahami Metode Kualitatif, Makara Sosial Humaniora, Vol 9 No.2 Desember 2005.

Raco J.R., Metode Penelitian Kualitatif, Jenis Karakteristik dan keunggulannya, Grasindo

Penerbit PT Gramedia Widiasarana Indonesia, Jakarta, 2010

Harahap Sofyan Syafri, The Disclosure Of Islamic Values - Annual Report The Analysis Of Bank Muamalat Indonesia's Annual Report, 2002.

Asmawi, Konseptualisasi Teori Maslahah, 2014, Salam; Jurnal Filsafat dan Budaya Hukum, November 2014.

Othman Rohana, Azlan Md Thani, Determinants of Islamic Social Reporting Among Top ShariahApproved Companies in Bursa Malaysia, 2009 Othman, Rohana; Thani, Azlan Md. Islamic Social Reporting Of Listed Companies in Malaysia. The International Business \& Economics Research Journal.April, 2010. 
Sunarsih Uun, Ferdiyansyah, Determinants of The Islamic Social Reporting Disclosure, 2016

Herawati $\mathrm{H}$, Maslahat Menurut Imam Malik Dan Imam Al- Ghazali (Studi Perbandingan), 2010.

Bedoui M. Houssem eddine, Shari'a-based ethical performance measurement framework, 2012.

Haniffa Roszaini, Mohammad Hudaib, Exploring the Ethical Identity of Islamic Banks via Communication in Annual Reports, 2007, Journal of Business Ethics (2007) 76:97-116

Muhammaddin, Kebutuhan Manusia Terhadap Agama, 2013, JIA Juni 2013 Th XIV Nomor 1

Mayangsari Galuh Nasrullah Kartika R, H.Hasni Noor, Konsep Maqasid Al Syariah dalam menentukan Hukum Islam, 2014, Al Iqtishadiyah Volume 1, Issue 1, Desember 2014. Muchlis Saiful, Anna Sutrisna Sukirman, Implementasi Maqasid Syariah Dalam Corporate Social Responsibility di PT Bank Muamalat Indonesia, 2016, Jurnal Akuntansi Multiparadigma Vol. 7, Nomor 1, 2016.

Shidiq Gofar, Teori Maqasid Syariah dalam Hukum Islam, 2009, Sultan Agung Vol XLIV No 118, Agustus 2009.
Auda Jasser, Maqid al-Sharah as Philosophy of Islamic Law A Systems Approach, 2007, The International Institute of Islamic Thought, 2007. Palupi Wening Purbatin, Harta Dalam Islam (Peran Harta Dalam Pengembangan Aktivitas Bisnis Islami), 2013, At-Tahdzib Vol.1 Nomor 2 Tahun 2013.

Romadhani Eka Laila, Rofiul Wahyudi, Pengaruh Islamic Corporate Identity (ICI) terhadap Kinerja Bank Syariah di Indonesia, Jurnal Muqtasid, Vol 6 No 2 Desember 2015.

Fuad Ikhwan, Menjaga Kesehatan Mental Perspetif Al-Quran dan Hadith, 2016, Jurnal An-nafs Vol.1 No.1 Jun 2016

Solichin Mohammad Muchlis, Tazkiyah Al-Nafs Sebagai Ruh Rekontruksi Sistem Pendidikan Islam, 2009, Tadrîs. Volume 4. Nomor 1. 2009.

Paramitasari Ratih, Islamic Corporate Identity in the Practice of Annual Report Disclosure Islamic Bank, 2012, ASSETS: Jurnal Akuntansi dan Pendidikan, Volume 1, Nomor 1, Oktober 2012 ILO Regional Office for Asia and the Pacific. Bangkok, Regional Model Competency Standards : core competencies / Regional Skills Programme, : ILO, 2015 